\title{
TRADE FACILITATION PERFORMANCE INFLUENCES ON ASEAN TRADE FLOWS
}

\author{
Anh Thu Nguyen ${ }^{1 *}$ and Thi Mai Thanh Tran² \\ 'Vietnam National University, University of Business and Economics, Hanoi, Vietnam \\ ${ }^{2}$ Vietnam Accademy of Social Sciences, Vietnam Institute of Economics, Hanoi, Vietnam
}

The Association of Southeast Asian Nations (ASEAN) considers trade facilitation as a driving force in forming a single market and a single production base. This paper constructs an ASEAN scorecard for measuring the performance of trade facilitation strategic plans by ASEAN member states. Next, a structural gravity model is used in the paper in order to estimate the trade facilitation performance influence on ASEAN trade flows. The fact that the indicator of easing Nontariff Barriers (NTBs) and institutional coordination, on the one hand, and the ASEAN member states' engagement indicator, on the other, had the highest enforcement scores in ASEAN in the period 2017-2019. Those two indicators also exert the biggest influence on ASEAN trade flows, especially ASEAN extra-regional trade.

Keywords: ASEAN, trade facilitation, trade flows

JEL Classification: F100, F140, F150

\section{INTRODUCTION}

Over the past decades, international trade has increased as a result of the trade barrier dismantling process, especially so tariff reduction and elimination. Recently, however, with relatively low tariff levels, the important and effective way to stimulate trade has been through trade facilitation initiatives, which includes the simplification of required paperwork, the modernization of procedures and the harmonization of customs requirements, among others.

* Correspondence to: A. T. Nguyen, Vietnam National University, University of Business and Economics, E4, 144 Xuan Thuy Street, Cau Giay, Hanoi, Vietnam; e-mail: thuna@vnu.edu.vn
The Association of Southeast Asian Nations (ASEAN) considers trade facilitation as an important driving force in transforming ASEAN into a single market and a single production base. ASEAN Trade Facilitation Framework (ATFF) was adopted in 2016. After its adoption, it was transferred to multi-action plans and strategic measures on the AEC (ASEAN Economic Community) 2025 Trade Facilitation Strategic Action Plan (ATF-SAP). It is expected that ASEAN member countries will strictly follow this action plan and that trade facilitation will significantly contribute to increasing the ASEAN trade flows through minimizing trade costs, promoting participation in global value chains, and increasing the participation of the private sector. 
Given the foregoing, there are two issues worth making a mention of and being dealt with in this paper. The first issue relates to the level of the trade facilitation performance of ASEAN and its member states, and the second issue relates to how the performance of ATF-SAP's trade facilitation measures affects the flow of ASEAN trade in goods inside the region and with other partners.

When the former issue is concerned, a scorecard adapted from the OECD trade facilitation indicators for measuring a trade facilitation strategic plan or actions cited in the ATF-SAP performed by ASEAN member states will be built. Speaking about the latter issue, a structural gravity model will be used to estimate the influence of trade facilitation performance on ASEAN trade flows, pointing out how ASEAN trade flows, especially intraregional trade flows, benefit when the ATF-SAP measures are implemented. The first hypothesis taken over from the literature reads that trade facilitation has a positive influence on trade flows through cutting unnecessary costs. The second hypothesis reads that the improvement of trade facilitation measures unevenly influences trade flows, both in intra-regional and in extra-regional trade. In the ASEAN case, the influence on extraregional trade is expected to be bigger since ASEAN are heavily dependent on the import of intermediate inputs from a country outside the region.

The rest of the paper is structured into a few sections. Section 2 presents a literature review and finds the research gap. In section 3, the background of trade in ASEAN and trade facilitation performance in ASEAN are provided, after which a scorecard for measuring that performance is formed. In Section 4, the data and methodology of the paper are described, and Section 5 is a presentation of the econometric specifications, and the empirical results of the estimation are discussed. Section 6 summarizes the results and provides conclusions.

\section{LITERATURE REVIEW}

One of the common findings of the literature is that trade facilitation has a positive influence on trade flows. Many studies show that trade facilitation reduces trade costs (World Bank, 2009; Hillberry \& Zhang, 2015; Nizeyimana \& De Wulf, 2016; Go, 2018), and increases trade flows (Iwanow \& Kirkpatrick, 2009; Sá Porto, Canuto \& Morini, 2015), which is particularly significant for developing countries (Moïsé \& Sorescu, 2013). Trade facilitation has a positive influence on time-sensitive goods, such as agricultural products and value-added chains (Martinez-Zarzoso \& Márquez-Ramos, 2008; Djankov, Freund \& Pham, 2010; Shepherd, 2013; Hoekman \& Shepherd, 2015; Volpe, Carballo \& Graziano, 2015). Trade facilitation helps to increase the diversification of developing countries' import and export markets (Shepherd, 2010; Dennis \& Shepherd, 2011; Persson, 2013), especially for small and medium-sized enterprises (Fontagné, Mitaritonna \& Signoret, 2016; Go, 2018).

Prior studies also show that different trade facilitation measures can differently influence trade flows. E. Moïsé and S. Sorescu (2013) pointed out the fact that the most significant trade facilitation measures (i.e. those that had the biggest influence on trade volumes) were information availability, the harmonization and simplification of documents, automated processes, risk management, the streamlining of border procedures, and good governance and impartiality. One amongst the groups of the measures exerting the most significant influence on a reduction in trade costs are the measures intended to modernize border operations reducing the time a business needs at the border (World Bank, 2009; Moïsé \& Sorescu, 2013; Hillberry \& Zhang, 2015; Nizeyimana \& De Wulf, 2016).

Some authors have developed their trade facilitation metrics, such as the infrastructure index (Limao \& Venables, 2001; Portugal-Perez \& Wilson, 2012; Francois \& Manchin, 2013), or they have conducted surveys, collected data to develop a set of indicators for port performance, the customs environment, the regulatory environment, and the use of e-commerce in APEC and in other countries (Wilson, Mann, \& Otsuki, 2003; 2005a; 2005b). B. Layton (2007) put forward a scorecard for measuring trade facilitation in ASEAN in terms of the customs, logistics 
performance, Single Window implementation, whereas other authors used scorecards to assess AEC integration (Findlay, 2009; Intal, 2015). The advantage of this method reflects in it being proactive in terms of data coverage by country and by time, but the same is limited with respect to the coverage of trade facilitation measures and the difficulty to regularly collect data in developing countries (Go, 2018).

While the ATF-SAP is a comprehensive trade facilitation strategic action plan, there has not been any scorecard measuring the ASEAN trade facilitation strategic measures and actions mentioned in the ATF-SAP. This also leads to a lack of studies on the influences of the ATF-SAP-related trade facilitation performance on ASEAN trade flows. Besides, many papers show that the improvement of trade facilitation performance unevenly influences bilateral trade with different partners. In the case of ASEAN member countries, how their intra- and extraregional trade flows differently benefit from different trade facilitation measures is also an interesting question to give an answer to.

\section{TRADE AND TRADE FACILITATION PERFORMANCE IN ASEAN}

\section{Trade facilitation in ASEAN}

The ASEAN Trade Facilitation Framework (ATFF) consolidates all the existing ASEAN obligations, commitments and instruments relating to trade facilitation. According to the ATFF, the scope of the ASEAN trade facilitation includes the four common areas and a few specialized areas. The four common areas include:

- the customs,

- trade rules and procedures transparency,

- standards and compliance, and

- the private sector participation.

Some specialized areas include the ASEAN Single Window (ASW), the ASEAN Customs Transit System
(ACTS), the ASEAN Trade Repository (ATR), the Self-Certification of the Origin in ASEAN, ASEAN Solutions to Investments, Services and Trade (ASSIST), and the Nontariff Barriers (NTBs) Reduction Initiatives. The contents of the ATFF were then concretized into the five strategic objectives and the 23 strategic actions and measures on trade facilitation in the ATF-SAP.

This paper builds a scorecard that combines the five ATF-SAP objectives and the OECD Trade Facilitation Indicators (OECD TFI) for measuring trade facilitation performance in ASEAN. The scorecard is constructed by the data extracted from the OECD TFI 2017 and 2019, which includes information on harmonization, the trade facilitation platform and modernization, easing NTBs, the private sector engagement, and institutional coordination and the engagement of the ASEAN member states (AMSs). The scorecard may be updated every two years.

To create a scorecard, the seven sub-category indicators properly aligned with the five strategic objectives of the ATF-SAP were chosen from the OECD TFI database. As ASEAN put no priorities on any strategic objectives, the scorecard treats them equally using the average calculation when measuring the aggregate indicators for a single ASEAN member state or for ASEAN as a whole.

The harmonization indicator compatible with the strategic objective number 1 (S.O.1) of the ATF-SAP is measured by the sub-category indicator $\mathrm{F}$ from the OECD TFI. $F$ refers to the simplification and harmonization of the document-related formalities. The trade facilitation platform and modernization match the strategic objective number 2 (S.O.2) and equal the average of the sub-category indicators $G$ and $\mathrm{H}$ in the OECD TFI. G refers to the automation and digitalization of the formalities, whereas $\mathrm{H}$ refers to the streamlining border procedures. The strategic objective number 3 (S.O.3) relates to easing NTBs and is covered by the average of the subcategory indicators A and C in the OECD TFI, which refer to the information availability and advance rulings, respectively. The strategic objective number 4 (S.O.4) which has to do with the private sector 
engagement well fitted the sub-category indicator $B$ in the OECD TFI, which implies the involvement of and consultation with the trade community. The strategic objective number 5 (S.O.5) of institutional coordination and AMSs engagement can be measured by the sub-category indicator $\mathrm{J}$ of border agency external cooperation in the OECD TFI.

As can be seen in Table 1, the ASEAN member states' trade facilitation performance in 2017 and 2019 shared the same picture. By country, Singapore, Thailand, Malaysia, Vietnam, and Brunei had higher average performance scores than ASEAN's average performance score, while Laos, Myanmar, and Cambodia lagged behind. Singapore had always been the country with the highest performance scores in ASEAN and throughout the world as well. The key driver behind the success of Singapore's trade facilitation performance was the miracle TradeNet - the World's first nationwide trade documentation system launched in 1989. Singapore continued its trade facilitation improvement by launching the National Trade Platform in 2017, which comprises various value-added services for trade, such as financing trade. On the other hand, Laos and Myanmar were the two ASEAN member states with

Table 1 The scorecard of ASEAN trade facilitation performance

\begin{tabular}{|c|c|c|c|c|c|c|c|c|c|c|c|c|c|}
\hline \multicolumn{14}{|c|}{2017} \\
\hline & TFI & $\begin{array}{l}\text { ATF- } \\
\text { SAP }\end{array}$ & ASEAN & BRN & KHM & IND & LAO & MYS & MMR & PHL & SGP & THA & VNM \\
\hline Average & & & 1.22 & 1.27 & 0.95 & 1.19 & 0.66 & 1.45 & 0.66 & 1.14 & 1.92 & 1.55 & 1.44 \\
\hline Harmonization & $\mathrm{F}$ & S.0.1 & 1.10 & 1.50 & 0.63 & 1.13 & 0.22 & 1.63 & 0.44 & 1.00 & 1.89 & 1.75 & 1.11 \\
\hline $\begin{array}{l}\text { Trade Facilitation } \\
\text { Platform and } \\
\text { Modernization }\end{array}$ & $\mathrm{G}, \mathrm{H}$ & S.0.2 & 1.14 & 1.42 & 0.88 & 0.98 & 0.57 & 1.17 & 0.46 & 0.99 & 1.90 & 1.60 & 1.42 \\
\hline Easing NTBs & $\mathrm{A}, \mathrm{C}$ & S.0.3 & 1.41 & 1.58 & 1.50 & 1.42 & 0.60 & 1.63 & 0.99 & 1.13 & 1.96 & 1.51 & 1.81 \\
\hline $\begin{array}{l}\text { Private Sector } \\
\text { Engagement }\end{array}$ & B & S.0.4 & 1.09 & 0.63 & 1.00 & 0.88 & 0.67 & 1.25 & 0.43 & 1.25 & 1.88 & 1.57 & 1.29 \\
\hline $\begin{array}{l}\text { Institutional } \\
\text { Coordination } \\
\text { and AMSs } \\
\text { Engagement } \\
\end{array}$ & $J$ & S.0.5 & 1.36 & 1.22 & 0.75 & 1.56 & 1.25 & 1.56 & 1.00 & 1.33 & 2.00 & 1.33 & 1.56 \\
\hline \multicolumn{14}{|c|}{2019} \\
\hline Average & TFI & $\begin{array}{l}\text { ATF- } \\
\text { SAP }\end{array}$ & 1.37 & 1.34 & 1.05 & 1.45 & 0.76 & 1.50 & 0.95 & 1.26 & 1.97 & 1.65 & 1.56 \\
\hline Harmonization & $\mathrm{F}$ & S.0.1 & 1.24 & 1.13 & 0.75 & 1.38 & 0.44 & 1.38 & 0.67 & 1.25 & 1.88 & 1.88 & 1.63 \\
\hline $\begin{array}{l}\text { Trade Facilitation } \\
\text { Platform and } \\
\text { Modernization }\end{array}$ & $\mathrm{G}, \mathrm{H}$ & S.0.2 & 1.29 & 1.58 & 0.89 & 1.28 & 0.82 & 1.35 & 0.46 & 1.00 & 2.00 & 1.82 & 1.39 \\
\hline Easing NTBs & $A, C$ & S.0.3 & 1.45 & 1.63 & 1.55 & 1.46 & 0.72 & 1.65 & 1.09 & 1.15 & 1.96 & 1.51 & 1.79 \\
\hline $\begin{array}{l}\text { Private Sector } \\
\text { Engagement }\end{array}$ & B & S.0.4 & 1.46 & 1.13 & 1.33 & 1.57 & 0.57 & 1.57 & 0.75 & 1.57 & 2.00 & 1.71 & 1.43 \\
\hline $\begin{array}{l}\text { Institutional } \\
\text { Coordination } \\
\text { and AMSs } \\
\text { Engagement }\end{array}$ & J & S.0.5 & 1.40 & 1.22 & 0.75 & 1.56 & 1.25 & 1.56 & 1.78 & 1.33 & 2.00 & 1.33 & 1.56 \\
\hline
\end{tabular}

Note: BRN (Brunei); KHM (Cambodia); LAO (Laos); IND (Indonesia); MYS (Malaysia); MMR (Myanmar); PHL (Philippines); SGP (Singapore); THL (Thailand); VNM (Vietnam)

Source: Authors 
the lowest trade facilitation scores. Both countries demonstrated the lowest harmonization score due to their poor compliance with international standards and the long time needed for preparing import and export documents.

In terms of the trade facilitation indicators, the NTB easing indicator and the indicators of institutional coordination and ASEAN member states' engagement show the highest enforcement scores both in 2017 and in 2019. The reason for that lies in ASEAN's establishment of the mechanisms and institutions to ensure the effective implementation of trade facilitation principles and ongoing reform commitments. The member states have their national legislative frameworks and/or institutional arrangements for cross-border trade regulator cooperation within the region, especially agreements to facilitate transit, including cooperation between the involved agencies as well. As a result, the member states have access to the necessary information and they also have the opportunities to discuss amendments to the laws and regulations of the other member countries as well. On the contrary, the indicators such as harmonization, the trade facilitation flatform, and modernization

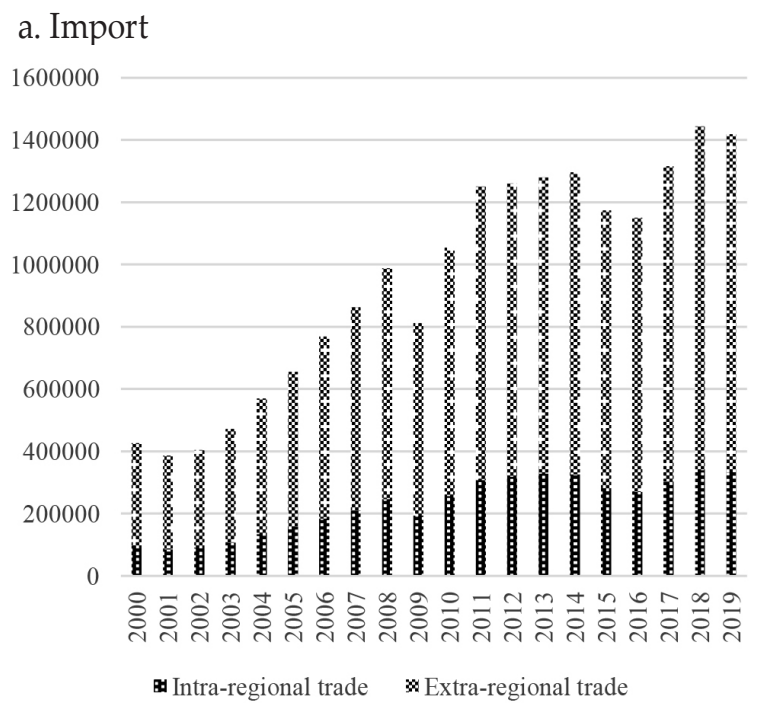

noticeably improved the scores from 2017 to 2019, with an increase of 0.14 and 0.15 points, respectively. ASEAN have modernized their border-crossing trade procedure system, which focuses on speeding up the customs procedures handling process, especially through the modern IT infrastructure and the ASW. ASEAN, however, is still experiencing a big gap in the performance capacity between its member states. The private sector engagement indicator had a remarkable increase by 0.35 points in the period from 2017 to 2019, as the ASEAN member states had developed the mechanism of public consultations between traders, other interested parties and the governments.

\section{Trade in ASEAN}

In the period from 2000 to 2019 (Figure 1), ASEAN trade in goods increased approximately 3.5 times. ASEAN's total trade volume in the year 2019 reached USD 2,802 billion, with a fairly balanced proportion of exports and imports. The export volume reached USD 1,418 billion, while the import volume was USD 1,384 billion. The ASEAN total trade volume significantly fluctuated from 2000 to 2019. It was experiencing strong growth in the period from 2000 to 2007, then

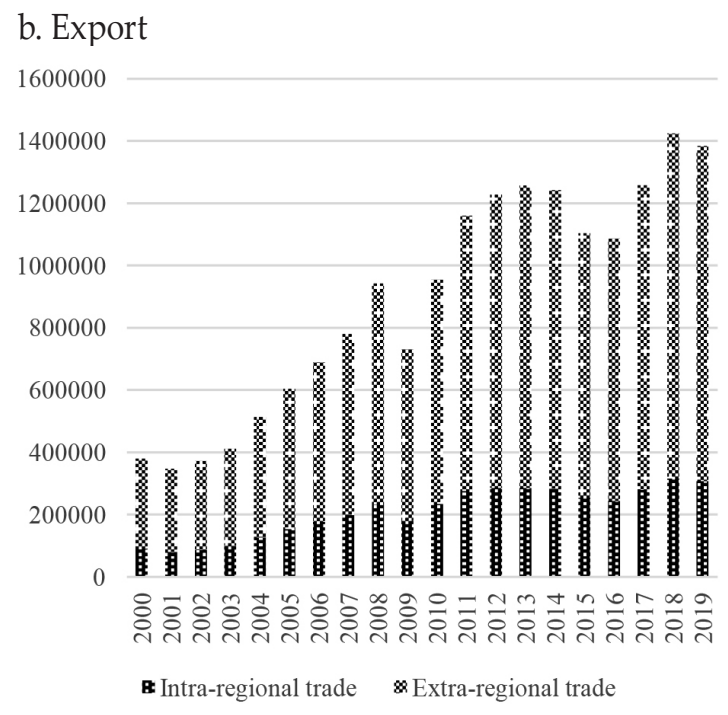

Figure 1 The ASEAN trade volume in the period from 2000 to 2019 
came a sharp decrease in the period from 2008 to 2010, due to the influence of the global financial crisis. After recovering and accelerating since 2011, ASEAN's total trade volume continued to decline in the period from 2014 to 2016, as a result of the cyclical recession in trade and the global economy. Trade flourished again in 2017, when the developed economies started to recover. In 2018, however, trade tensions exacerbated global uncertainties and hampered global economic growth, causing a decline in the trade volume in 2019.

Extraregional trade made up a dominant share in ASEAN total trade and became the main channel for transmitting the world economy's upheavals to the ASEAN economy. Conversely, ASEAN intraregional trade share witnessed no significant improvement during the period from 2010 to 2019, not even so after the milestone of the establishment of the AEC in the year 2015 (Figure 2). The share of ASEAN intraregional exports and imports in 2019 were merely $23.52 \%$ and $22.38 \%$, respectively, namely significantly lower than those of the ASEAN+3 region $(35.89 \%$ and $42.92 \%$, respectively) and APEC (69.13\% and 69\%, respectively) in the same period.

According to the AEC Blueprint, ASEAN will strive for intraregional trade to double from 2017 through

a. The share of intraregional imports

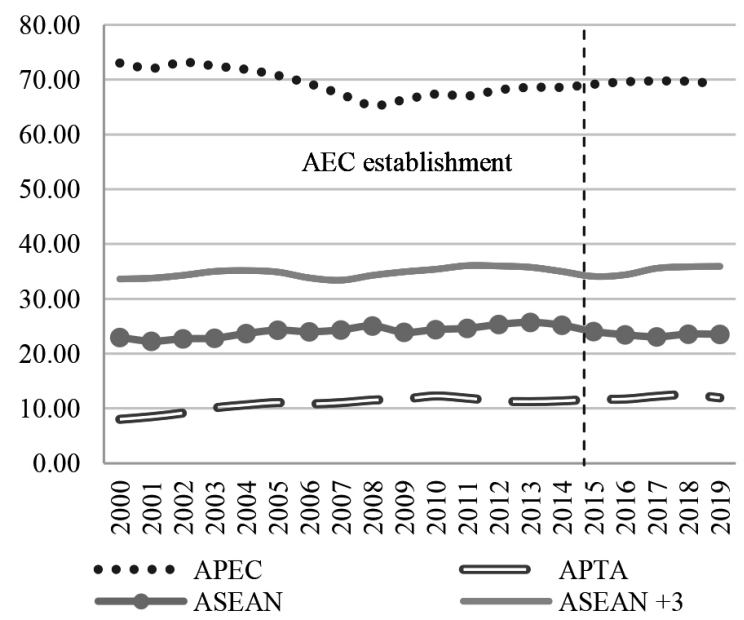

2025. As the intra-ASEAN trade volume of 2017 reached more than USD 583 billion, according to the AEC's target, the annual growth rate of intraregional trade in the period from 2017 to 2025 will have to reach $7.8 \%$. The average ASEAN trade growth rate in the period from 2017 to 2019 was only $6.6 \%$. Therefore, ASEAN have to make more efforts to promote regional economic integration for further boosting intraregional trade. Implementing trade facilitation is not only meaningful for intraregional trade, but it is also meaningful for ensuring the imports of intermediate goods, which is significant for the production expansion in the ASEAN member countries. The influence of trade facilitation on ASEAN intraregional and extraregional trade is measured in the following section of the paper.

\section{METHODOLOGY AND DATA}

To begin with, the standard gravity model reads as follows:

$$
\text { Trade }=X \beta+z \gamma+\varepsilon
$$

In equation (1), $X$ contains the traditional gravity variables, such as the GDP, the bilateral distance

b. The share of intraregional exports

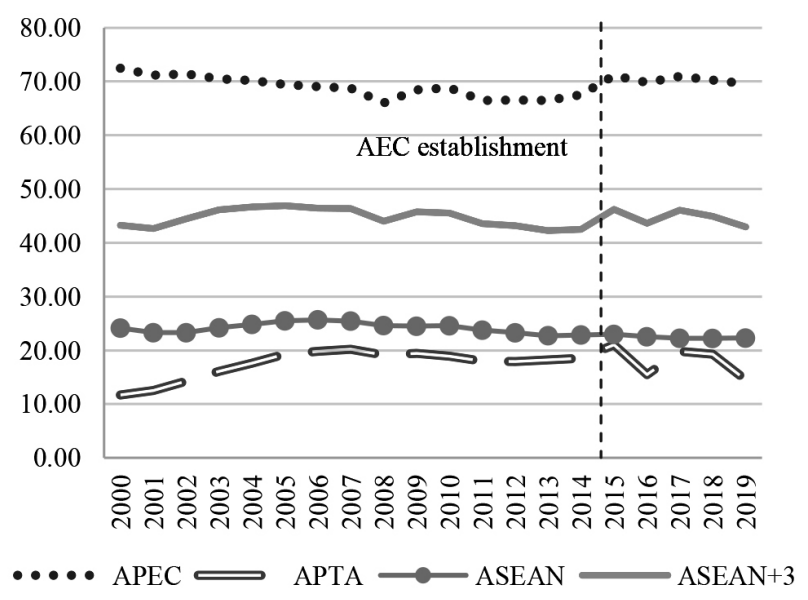

Figure 2 The share of intraregional imports and export in some regions in Asia-Pacific (\%)

Source: Authors 
between exporters and importers, while $\mathrm{z}$ refers to the numerous influencing factors, such as the common language, the common border, and trade facilitation. Then, the equation (1) is so customized as to quantify the influence of trade facilitation on ASEAN trade flows as follows:

$$
\begin{aligned}
& \text { Trade } e_{i j}^{t}=a_{i j}+a_{1} \operatorname{lnDIST}+a_{2} \text { contig }+a_{3} \text { COMLANG } \text { ETHNO }_{\text {O }} \\
& +a_{4} \text { colony }+a_{5} \text { comcol }+a_{6} \ln \_G D P i+a_{7} \ln G \mathrm{GDPj} \\
& +a_{8} l n \_T F j+a_{9} \ln { }_{-} R E M_{-} I M P+a_{10} \ln \_ \text {REM_EXP } \\
& +e^{t}
\end{aligned}
$$

where $i$ denotes ten AMSs and $j$ denotes the 88 trading partners of the AMSs; $t$ implies the years from 2017 to 2019; $e_{i j, t}$ is an error term, and Trade $e_{i j, t}$ denotes the trade volume of the country (i) with the country $(j)$ in the year $(t) ; G D P_{i}^{t}$ and $G D P^{t}$ describe the gross domestic product (GDP) of the country (i) and the country (j) in the year t, respectively. COMLANG ${ }_{\text {ETHNO }}$ is the dummy variable that is set to 1 if two countries have a language spoken by at least $9 \%$ of the population in both countries. Contig and comcol are the dummy variables in the case when two countries are contiguous and in colonial relations, respectively. DIST refers to the bilateral distances between the biggest cities of those two countries. $T F_{i}$ is the trade facilitation variable that measures the AMS's average trade facilitation performance in Table 1.

After estimating the equation (2) with the TFi variable, we continue with the component indicators Ham, Pla, Eas, Pri, and Ins, which are each AMS's Harmonization Indicator, the Trade Facilitation Platform and Modernization Indicator, the NTB Easing Indicator, the Private Sector Engagement Indicator, the Institutional Coordination Indicator, and the AMS Engagement Indicator in the five different gravity estimations. Except for the dummy variables, all the other variables used are a natural logarithmic scale.

The gravity model serves as a broadly used empirical piece of equipment for assessing the influences of the factors exerting an influence on the bilateral trade flows. Nevertheless, the gravity estimation faces challenges of the unobserved and nondiscrimination trade policy variables. The former comes from the fact that multilateral resistances are hardly observed by researchers or policymakers (Piermartini \& Yotov, 2016). The solution proposed by J. E. Anderson and E. Van Wincoop (2003) for this challenge which implies using iterative custom programming is simplified to the reduced form of the custom treatment, in which multilateral resistance (MR) terms are measured by the remoteness indices (Baier \& Berstrand, 2007) as in the following equations:

$$
\begin{aligned}
& R E M_{-} E X P_{i, t}=\left(\sum_{j} D I S T_{i j} / \frac{Y_{j, t}}{Y_{t}}\right) \\
& R E M_{-} I M P_{\mathrm{j}, t}=\left(\sum_{j} D I S T_{i j} / \frac{Y_{i, t}}{Y_{t}}\right)
\end{aligned}
$$

REM_EXP ${ }_{i, t}$ and REM_IMP ${ }_{j, t}$ are the new covariates on the exporter's side and on the importer's side, respectively. REM_EXP ${ }_{i, t}$ equals the importer $j$ 's output-weighted averages of the bilateral distance, whereas REM_IMP ${ }_{i, t}$ equals the exporter i's outputweighted averages of the bilateral distance. Although $R E M_{-} E X P_{i, t}$ and REM_IMP ${ }_{j, t}$ have insignificant influences on gravity estimation results (Anderson \& Van Wincoop, 2003), they are still used in empirical research (Rahman, 2003; Kepaptsoglou, Karlaftis, \& Tsamboulas, 2010; Felipe \& Kumar, 2012) because these variables help to identify the effects related to the nondiscriminatory trade facilitation policies on the importer's side (Piermartini \& Yotov, 2016). Therefore, expanding the equation (2) by adding thje REM_ $E X P_{i, t}$ and REM_IMP ${ }_{j, t}$ variables will solve the two challenges of the unobserved and nondiscrimination trade policy variables.

Poisson Pseudo Maximum Likelihood (PPML) estimation is used in the paper to solve the challenges in estimating the influence of trade facilitation on the ASEAN trade flows related to a zero-trade flow, variance change (Silva \& Tenreyro, 2006).

In terms of the data, the GDP and the trade volume were obtained from the UNCTADstat database. All the data are expressed in the US dollars. The data on the distance, the language, and the border employed within this research study are drawn from the website of the Centre d'Etudes Prospectives et d'Informations 
Internationales (CEPII). The scorecards that track the AMS trade facilitation performance are extracted from the OECD Trade Facilitation Indicators (TFIs) from 2017 to 2019.

\section{EMPIRICAL SPECIFICATIONS AND RESULTS}

Table 2 shows the results of the estimates of the equation (2) using the PPML estimation in the AMS trade relations with 88 countries. Except for the comcol variables that are not statistically significant, the model's estimated results are consistent with the expectation. Column 1 shows the results of the estimated gravity model with the aggregated trade facilitation variable TFi (the average score of trade facilitation performance among the AMSs). The size of the trading partners' economies positively affects ASEAN trade flows, the ASEAN partners' GDP having a greater positive influence on the trade flows and being statistically significant as compared to the AMSs' GDP. Conversely, the relative distance is statistically significant, but has a small positive effect on ASEAN's trade flows.

The countries with the common border (contig) trade more than the countries that do not share the border. This reflects the nature of the ASEAN's regional value chains, where the intermediate inputs imported from East Asia - the countries with relatively close physical distances - account for a big proportion.

Aggregated trade facilitation performance (TFi) is the factor that exerts the biggest influence on ASEAN trade flows. When the AMSs reform their trade facilitation measures according to the ATF-SAP so as to increase trade facilitation performance by $1 \%$, the ASEAN trade volume will grow by over USD 0.11 billion. When trade facilitation performance is disaggregated into the five indicators, different influences on the ASEAN trade flows are shown in columns 2, 3, 4, 5 and 6. The improvement of Easing NTBs (Eas) boosts the ASEAN trade flows most significantly among all the five indicators. A percentage increase in the Easing NTBs score will make the ASEAN trade flows increase by USD 0.17 billion. Institutional Coordination and AMSs Engagement (Ins) show the second biggest influence, with an increase of USD 0.12 billion in the trade flow. The one-percent-improvement gains of the trade flow achieved in the Harmonization, Trade Facilitation Platform and Modernization, and Private Sector Engagement indicators are approximately 0.077, 0.072, and 0.051 billion American dollars, respectively.

The elasticity of the ASEAN intraregional trade flows to the trade facilitation reforms is smaller than that of ASEAN trade with 88 global partners at both aggregated and disaggregated levels. Intraregional trade flows go up by USD 0.077 billion when the aggregated TFi scores increase by $1 \%$ (Table 3, Column 7). TFi is still the determinant with the strongest effect on ASEAN intraregional trade flows. At the disaggregated level, the results of the equation (II) PPML estimation significantly diversify in terms of the influences exerted by the trade facilitation reforms on intraregional trade flows. Intraregional trade increases by one billion American dollars in response to one additional percent gain in Easing NTBs performance. This finding is similar to the suggestion made by E. Moïsé and S. Sorescu (2013), according to whom the influence of the available information about the worldwide export of low- and middle-income countries is stronger than the influences exerted by many other TFI areas. Information availability and advance rulings affect the fixed cost component of trade, which becomes one of the trade facilitation areas that most consistently influence the small firms' export volume (Fontagné et al, 2016). Besides, Institutional Coordination and AMSs Engagement exert the second-biggest influence on the ASEAN intraregional trade flow when the improvement of this indicator by one percent brings an additional growth of 0.08 billion American dollars of ASEAN intraregional trade, strongly confirming the role of cooperation in the trade facilitation framework inside ASEAN. Although the Trade Facilitation Platform and Modernization, and Private Sector Engagement are the two areas with the smallest influence on ASEAN intraregional trade flows, their positive and significant coefficients properly fit in with the other authors' findings on the role of automation in trade 
Table 2 The experimental results of the AMSs and 88 partners

\begin{tabular}{|c|c|c|c|c|c|c|}
\hline & $\begin{array}{c}1 \\
\text { Trade }\end{array}$ & $\begin{array}{c}2 \\
\text { Trade }\end{array}$ & $\begin{array}{c}3 \\
\text { Trade }\end{array}$ & $\begin{array}{c}4 \\
\text { Trade }\end{array}$ & $\begin{array}{c}5 \\
\text { Trade }\end{array}$ & $\begin{array}{c}6 \\
\text { Trade }\end{array}$ \\
\hline In_DIST & $\begin{array}{l}-0.170^{*} \\
(-2.01)\end{array}$ & $\begin{array}{l}-0.170^{*} \\
(-2.01)\end{array}$ & $\begin{array}{l}-0.173^{*} \\
(-2.06)\end{array}$ & $\begin{array}{l}-0.181^{*} \\
(-2.17)\end{array}$ & $\begin{array}{l}-0.188^{*} \\
(-2.22)\end{array}$ & $\begin{array}{l}-0.176^{*} \\
(-2.05)\end{array}$ \\
\hline contig & $\begin{array}{c}0.521 * * \\
(2.91)\end{array}$ & $\begin{array}{l}0.531^{* *} \\
(2.88)\end{array}$ & $\begin{array}{c}0.534^{* *} \\
(3.07)\end{array}$ & $\begin{array}{l}0.502^{* *} \\
(2.95)\end{array}$ & $\begin{array}{l}0.502^{* *} \\
(2.89)\end{array}$ & $\begin{array}{c}0.438^{*} \\
(2.31)\end{array}$ \\
\hline comlang_ethno & $\begin{array}{l}0.463^{* *} \\
(3.08)\end{array}$ & $\begin{array}{c}0.471 * * \\
(3.18)\end{array}$ & $\begin{array}{c}0.484^{* * *} \\
(3.36)\end{array}$ & $\begin{array}{c}0.559^{* * * *} \\
(4.07)\end{array}$ & $\begin{array}{c}0.579^{* * *} \\
(4.19)\end{array}$ & $\begin{array}{l}0.414^{* *} \\
(2.75)\end{array}$ \\
\hline comcol & $\begin{array}{l}0.202 \\
(0.93)\end{array}$ & $\begin{array}{l}0.210 \\
(0.97)\end{array}$ & $\begin{array}{l}0.229 \\
(1.07)\end{array}$ & $\begin{array}{l}0.192 \\
(0.89)\end{array}$ & $\begin{array}{l}0.290 \\
(1.38)\end{array}$ & $\begin{array}{l}0.173 \\
(0.82)\end{array}$ \\
\hline In_GDPi & $\begin{array}{c}0.497^{* * * *} \\
(8.49)\end{array}$ & $\begin{array}{c}0.507^{* * * *} \\
(8.74)\end{array}$ & $\begin{array}{c}0.528^{* * * *} \\
(9.54)\end{array}$ & $\begin{array}{c}0.451^{1 * * *} \\
(8.17)\end{array}$ & $\begin{array}{c}0.480^{* * * *} \\
(8.01)\end{array}$ & $\begin{array}{c}0.622 * * * \\
(9.06)\end{array}$ \\
\hline In_GDPj & $\begin{array}{c}0.767^{* * * *} \\
(25.02)\end{array}$ & $\begin{array}{c}0.767^{* * * *} \\
(25.00)\end{array}$ & $\begin{array}{c}0.769 * * * \\
(25.28)\end{array}$ & $\begin{array}{c}0.767^{* * *} \\
(25.78)\end{array}$ & $\begin{array}{c}0.774^{* * * *} \\
(25.18)\end{array}$ & $\begin{array}{c}0.769^{* * * *} \\
(25.56)\end{array}$ \\
\hline In_TFi & $\begin{array}{c}1.118^{* * *} \\
(5.26)\end{array}$ & & & & & \\
\hline In_Ham & & $\begin{array}{c}0.769 * * * \\
(5.6)\end{array}$ & & & & \\
\hline In_Pla & & & $\begin{array}{c}0.752^{* * *} \\
(5.4)\end{array}$ & & & \\
\hline In_Eas & & & & $\begin{array}{c}1.658 * * * \\
(7.26)\end{array}$ & & \\
\hline In_Pri & & & & & $\begin{array}{c}0.511 * * * \\
(3.38)\end{array}$ & \\
\hline In_Ins & & & & & & $\begin{array}{c}1.185^{* * *} \\
(6.88)\end{array}$ \\
\hline Ln_REM_EXP & $\begin{array}{c}-0000000235^{* * *} \\
(-6.34)\end{array}$ & $\begin{array}{c}-0000000234^{* * *} \\
(-6.32)\end{array}$ & $\begin{array}{c}-0000000232^{* * *} \\
(-6.30)\end{array}$ & $\begin{array}{c}-0000000230^{* * *} \\
(-6.36)\end{array}$ & $\begin{array}{c}-0000000228 * * * \\
(-5.99)\end{array}$ & $\begin{array}{c}-0000000234^{* * *} \\
(-6.24)\end{array}$ \\
\hline Ln_REM_IMP & $\begin{array}{c}0.0000000000547^{* * *} \\
(2.03)\end{array}$ & $\begin{array}{c}0.0000000000032^{* * *} \\
(1.20)\end{array}$ & $\begin{array}{c}0.0000000000044^{1 * * *} \\
(1.62)\end{array}$ & $\begin{array}{c}0.00000000000960^{* * *} \\
(3.84)\end{array}$ & $\begin{array}{c}0.00000000000765^{* * *} \\
(2.95)\end{array}$ & $\begin{array}{c}0.00000000000803^{* * *} \\
(3.05)\end{array}$ \\
\hline _cons & $\begin{array}{l}0.446 \\
(0.46)\end{array}$ & $\begin{array}{l}0.568 \\
(0.59)\end{array}$ & $\begin{array}{l}0.252 \\
(0.27)\end{array}$ & $\begin{array}{l}0.625 \\
(0.67)\end{array}$ & $\begin{array}{l}0.795 \\
(0.83)\end{array}$ & $\begin{array}{r}-1.205 \\
(-1.11)\end{array}$ \\
\hline $\mathrm{N}$ & 1780 & 1780 & 1780 & 1780 & 1780 & $1780^{\prime}$ \\
\hline
\end{tabular}

t statistics in parentheses * $p<0.05,{ }^{* *} p<0.01,{ }^{* * *} p<0.001$

Source: Authors

costs prediction (Hillberry \& Zhang, 2015) and trade flows prediction (Moïsé \& Sorescu, 2013), in which single windows strongly lead to an increase in trade flows (Sá Porto et al, 2015).

\section{CONCLUSIONS}

The scorecard that combines the ATF-SAP objectives and the TFI of the AMSs has given a general picture of ASEAN trade facilitation performance. There is significant differentiation in trade facilitation performance among the AMSs, in which Singapore, Thailand, Malaysia, Vietnam, and Brunei have higher performance scores, whereas Laos, Myanmar, and Cambodia still lag behind. Among the ATFSAP's action lines, the NTB Easing and Institutional Coordination and the AMS Engagement indicators are always the groups with the highest enforcement scores. Nevertheless, those indicators did not see much improvement in the period from 2017 to 2019, whereas the Harmonization and Trade Facilitation 
Table 3 The experimental results of ASEAN intraregional trade

\begin{tabular}{|c|c|c|c|c|c|c|}
\hline & $\begin{array}{c}7 \\
\text { trade }\end{array}$ & $\begin{array}{c}8 \\
\text { trade }\end{array}$ & $\begin{array}{c}9 \\
\text { trade }\end{array}$ & $\begin{array}{l}10 \\
\text { trade }\end{array}$ & $\begin{array}{c}11 \\
\text { trade }\end{array}$ & $\begin{array}{c}12 \\
\text { trade }\end{array}$ \\
\hline In_DIST & $\begin{array}{l}-0.345^{*} \\
(-1.89)\end{array}$ & $\begin{array}{l}-0.366^{*} \\
(-2.18)\end{array}$ & $\begin{array}{l}-0.355^{*} \\
(-2.17)\end{array}$ & $\begin{array}{l}-0.370^{*} \\
(-2.16)\end{array}$ & $\begin{array}{l}-0.410^{*} \\
(-2.50)\end{array}$ & $\begin{array}{l}-0.334^{*} \\
(-1.82)\end{array}$ \\
\hline contig & $\begin{array}{l}0.0834 \\
(0.28)\end{array}$ & $\begin{array}{l}0.0953 \\
(0.33)\end{array}$ & $\begin{array}{l}0.0447 \\
(0.16)\end{array}$ & $\begin{array}{l}0.0270 \\
(0.09)\end{array}$ & $\begin{array}{l}-0.0296 \\
(-0.10)\end{array}$ & $\begin{array}{l}0.0691 \\
(0.22)\end{array}$ \\
\hline comlang_ethno & $\begin{array}{l}0.578^{* *} \\
(2.03)\end{array}$ & $\begin{array}{l}0.569 * * \\
(2.68)\end{array}$ & $\begin{array}{l}0.583^{* *} \\
(2.69)\end{array}$ & $\begin{array}{l}0.566^{* *} \\
(2.63)\end{array}$ & $\begin{array}{l}0.603^{* *} \\
(2.83)\end{array}$ & $\begin{array}{c}0.607^{* * *} \\
(2.81)\end{array}$ \\
\hline comcol & $\begin{array}{l}0.738^{*} \\
(2.03)\end{array}$ & $\begin{array}{l}0.715 \\
(1.92)\end{array}$ & $\begin{array}{l}0.759^{*} \\
(2.09)\end{array}$ & $\begin{array}{l}0.774^{*} \\
(2.17)\end{array}$ & $\begin{array}{l}0.813^{*} \\
(2.35)\end{array}$ & $\begin{array}{l}0.677 \\
(1.90)\end{array}$ \\
\hline In_GDPi & $\begin{array}{c}0.552^{* * * *} \\
(5.01)\end{array}$ & $\begin{array}{c}0.557^{* * * *} \\
(5.01)\end{array}$ & $\begin{array}{c}0.524 * * * \\
(4.81)\end{array}$ & $\begin{array}{c}0.578 * * * \\
(5.42)\end{array}$ & $\begin{array}{c}0.533 * * * \\
(4.98)\end{array}$ & $\begin{array}{c}0.6 .21 * * * \\
(5.17)\end{array}$ \\
\hline In_GDPj & $\begin{array}{c}0.716 * * * \\
(10.10)\end{array}$ & $\begin{array}{c}0.712 * * * \\
(10.04)\end{array}$ & $\begin{array}{c}0.721^{* * *} \\
(9.99)\end{array}$ & $\begin{array}{c}0.721^{* * *} \\
(10.17)\end{array}$ & $\begin{array}{c}0.726 * * * \\
(10.37)\end{array}$ & $\begin{array}{c}0.6 .97^{* * *} \\
(9.92)\end{array}$ \\
\hline $\begin{array}{l}\text { In_TFi } \\
\text { In_Ham }\end{array}$ & $\begin{array}{c}0.765^{* * *} \\
(3.49)\end{array}$ & $0.548^{* * *}$ & & & & \\
\hline In_Pla & & (3.95) & $\begin{array}{c}0.492 * * * \\
(3.55)\end{array}$ & & & \\
\hline In_Eas & & & & $\begin{array}{c}1.049 * * * \\
(4.5)\end{array}$ & & \\
\hline In_Pri & & & & & $\begin{array}{c}0.432^{* * *} \\
(2.97)\end{array}$ & \\
\hline In_Ins & & & & & & $\begin{array}{c}0.789 * * * \\
(3.84)\end{array}$ \\
\hline REM_EXP & $\begin{array}{c}-0000000753^{* * *} \\
(-3.49)\end{array}$ & $\begin{array}{c}-0000000732^{* * *} \\
(-3.40)\end{array}$ & $\begin{array}{c}-0000000733^{* * *} \\
(-3.26)\end{array}$ & $\begin{array}{c}-0000000744^{* * *} \\
(-3.42)\end{array}$ & $\begin{array}{c}-0000000773^{* * *} \\
(-3.40)\end{array}$ & $\begin{array}{c}-0000000683^{* * *} \\
(-3.18)\end{array}$ \\
\hline REM_IMP & $\begin{array}{c}0.0000000703^{*} \\
(2.30)\end{array}$ & $\begin{array}{c}0.0000000684^{*} \\
(2.27)\end{array}$ & $\begin{array}{c}0.0000000793^{* *} \\
(2.77)\end{array}$ & $\begin{array}{c}0.0000000715^{*} \\
(2.32)\end{array}$ & $\begin{array}{c}0.0000000823^{* *} \\
(2.86)\end{array}$ & $\begin{array}{c}0.0000000749^{*} \\
(2.44)\end{array}$ \\
\hline cons & $\begin{array}{l}2.799 \\
(1.04)\end{array}$ & $\begin{array}{l}3.075 \\
(1.14)\end{array}$ & $\begin{array}{l}2.903 \\
(1.09)\end{array}$ & $\begin{array}{l}2.739 \\
(1.01)\end{array}$ & $\begin{array}{l}3.494 \\
(1.35)\end{array}$ & $\begin{array}{l}1.949 \\
(0.68)\end{array}$ \\
\hline $\mathrm{N}$ & 180 & 180 & 180 & 180 & 180 & 180 \\
\hline
\end{tabular}

t statistics in parentheses ${ }^{*} p<0.05,{ }^{* *} p<0.01,{ }^{* * *} p<0.001$

Source: Authors

Platform and Modernization indicators experienced the strongest reforms. The scorecard created from this research study can be updated and utilized further in other research studies dealing with ASEAN trade facilitation.

The gravity model's results confirm all the hypotheses of this paper. Firstly, aggregated trade facilitation performance apparently has positive influences on ASEAN trade flows. Secondly, different trade facilitation indicators have uneven influences on ASEAN trade flows. The NTB Easing and Institutional Coordination and AMS Engagement indicators are also the most influential factors when their influence on ASEAN trade flows, especially ASEAN extraregional trade, is concerned. The Trade Facilitation Platform and Modernization, and the Private Sector Engagement indicators demonstrate modest influences. Thirdly, the influence of trade facilitation reforms on intraregional trade flows is smaller than that of ASEAN extraregional trade at both aggregated and disaggregated levels.

These findings may put forward some recommendations for ASEAN in the trade facilitation reform priority setting process. The first priority 
should be to continue further easing of NTBs that regulate the cross-border trade, high commitment to international institutional coordination. If a country chooses to invest in modernizing its crossborder trade management infrastructure and procedures instead of improving the other ATF-SAP's trade facilitation measures, its trade volume will benefit less. In addition, modernizing cross-border trade management procedures has not been fully implemented in many ASEAN countries, especially the measures intended to exchange electronic import and export documents and electronic applications, too. The SPS registration and certification come along with remarkable challenges, significant financial costs, and donors' technical assistance for implementation. Therefore, ASEAN member states have to carefully take into account both costs and benefits when making any decision on reforming these trade facilitation measures.

In order to be able to ensure a deep analysis of and good alignment with the content of the ATF-SAP, the research scope of the paper does not include the infrastructure, transportation, and logistics contents, thus simultaneously not including their influences on ASEAN trade flows, either. This could be extended in a future study of ours, since the performance of the infrastructure, transportation and logistics also playa a very important role in achieving the common goal of establishing a single ASEAN market and a single ASEAN production base. The one fact that should be taken into account is the Covid-19 pandemic, which has led to an abrupt break in international trade. Trade facilitation has strongly been affected by the pandemic, but it may also be an important factor boosting trade recovery from the pandemic. The priority of trade facilitation measures in the times of the pandemic can be different from the abovementioned suggestions since modernizing cross-border trade management procedures, especially electronic and digital applications, are expected to be proper solutions in the pandemic times. Therefore, a further study of digital trade facilitation is needed in the pandemic times.

\section{ACKNOWLEDGMENTS}

This research is funded by Vietnam National University, Hanoi (VNU), under the Project number QG.19.43 entitled "International Economic Integration of Vietnam: Trade and Investment Facilitation".

\section{REFERENCES}

Anderson, J. E., \& Van Wincoop, E. (2003). Gravity with gravitas: A solution to the border puzzle. American economic review, 93(1), 170-192. doi:10.1257/000282803321455214

Baier, S. L., \& Bergstrand, J. H. (2007). Do free trade agreements increase members' international trade? Journal of International Economics, 71(1), 72-95. doi.org/10.1016/j. jinteco.2006.02.005

Dennis, A., \& Shepherd, B. (2011). Trade facilitation and export diversification. The World Economy, 34(1), 101-122. doi.org/10.1111/j.1467-9701.2010.01303.x

Djankov, S., Freund, C., \& Pham, C. S. (2010). Trading on time. The Review of Economics and Statistics, 92(1), 166-173. doi/pdf/10.1162/rest.2009.11498

Felipe, J., \& Kumar, U. (2012). The role of trade facilitation in Central Asia: A gravity model. Eastern European economics, 50(4), 5-20. doi.org/10.2753/EEE0012-8775500401

Findlay, C. (2009). Trade Facilitation in the ASEAN Economic Community. Working Papers PB-2009-06, Economic Research Institute for ASEAN and East Asia.

Fontagné, L., Mitaritonna, C., \& Signoret, J. (2016). Estimated tariff equivalents of services NTMs. Working Papers No 2016-20. CEPII research center.

Francois, J., \& Manchin, M. (2013). Institutions, infrastructure, and trade. World Development, 46(C), 165-175. doi:10.1016/j. worlddev.2013.02.009

Go, E. (2018). Contribution and Effectiveness of Trade Facilitation Measure: A Structured Literature Review, World Bank Group, Washington, DC.

Hillberry, R., \& Zhang, X. (2015). Policy and performance in customs. Policy Research Working Paper 7211, World Bank Group, Washington, DC. 
Hoekman, B., \& Shepherd, B. (2015). Who profits from trade facilitation initiatives? Implications for African countries. Journal of African Trade, 2(1-2), 51-70. doi.org/10.1016/j. joat.2015.08.001

Intal, P. (2015). AEC blueprint implementation performance and challenges: Trade facilitation. Working Papers DP-201541, Economic Research Institute for ASEAN and East Asia (ERIA).

Iwanow, T., \& Kirkpatrick, C. (2009). Trade facilitation and manufactured exports: Is Africa different? World Development, 37(6), 1039-1050. doi.org/10.1016/j. worlddev.2008.09.014

Kepaptsoglou, K., Karlaftis, M. G., \& Tsamboulas, D. (2010). The gravity model specification for modeling international trade flows and free trade agreement effects: a 10-year review of empirical studies. The open economics journal, 3(1), 1-13. doi.org/10.2174/1874919401003010001

Layton, B. (2007). Trade Facilitation: A study in the context of the ASEAN Economic Community Blueprint. In H. Soesastro, (Ed.). Deepening Economic Integration - The ASEAN Economic Community and Beyond (pp. 76-100). ERIA Research Project Report 2007, 1-2.

Limao, N., \& Venables, A.J. (2001). Infrastructure, geographical disadvantage, transport costs, and trade. The world bank economic review, 15(3), 451-479. doi:10.1093/wber/15.3.451

Martinez-Zarzoso, I., \& Márquez-Ramos, L., (2008). The effect of trade facilitation on sectoral trade. Journal of Economic Analysis \& Policy, 8(1), 1-46. doi:10.2202/1935-1682.1927

Moïsé, E., \& Sorescu, S. (2013). Trade facilitation indicators: The potential impact of trade facilitation on developing countries' trade. OECD Trade Policy Working Papers No. 144. doi.org/10.1787/5k4bw6kg6ws2-en

Nizeyimana, C., \& De Wulf, L. (2015). Rwanda electronic single window supports trade facilitation. World Customs Journal, 9(2), 73-84.

Persson, M. (2013). Trade facilitation and the extensive margin. The Journal of International Trade \& Economic Development, 22(5), 658-693. doi:10.1080/09638199.2011.587019

Piermartini, R., \& Yotov, Y. (2016). Estimating trade policy effects with structural gravity. WTO Staff Working Paper, No. ERSD-2016-10, World Trade Organization, Geneva.
Portugal-Perez, A., \& Wilson, J. S. (2012). Export performance and trade facilitation reform: Hard and soft infrastructure. World Development, 40(7), 1295-1307. doi:10.1016/j. worlddev.2011.12.002

Rahman, M. M. (2003, September). A panel data analysis of Bangladesh's trade: the gravity model approach. Paper presented an the $5^{\text {th }}$ Annual Conference of the European Trade Study Group (ETSG2003), Madrid, ES.

Sá Porto, P. C. D., Canuto, O., \& Morini, C. (2015). The impacts of trade facilitation measures on international trade flows. Policy Research Working Paper; No. 7367. World Bank, Washington, DC.

Shepherd, B. (2010). Trade Costs and Facilitation in APEC and ASEAN: Delivering the Goods? MPRA Paper No. 21531, University Library of Munich, Germany.

Shepherd, B. (2013). Trade times, importing and exporting: firm-level evidence. Applied Economics Letters, 20(9), 879-883. doi.org/10.1080/13504851.2012.756574

Silva, J. S., \& Tenreyro, S. (2006). The log of gravity. The Review of Economics and Statistics, 88(4), 641-658. doi.org/10.1162/ rest.88.4.641

Tinbergen, J. (1963). Shaping the world economy. The International Executive, 5(1), 27-30. doi.org/10.1002/ tie. 5060050113

Volpe, M. C., Carballo, J., \& Graziano, A. (2015). Customs. Journal of International Economics, 96(1), 119-137. doi.org/10.1016/j.jinteco.2015.01.011

Wilson, J. S., Mann, C. L., \& Otsuki, T. (2003). Trade facilitation and economic development: A new approach to quantifying the impact. The World Bank Economic Review, 17(3), 367-389. doi.org/10.1093/wber/lhg027

Wilson, J. S., Mann, C. L., \& Otsuki, T. (2005a). Assessing the benefits of trade facilitation: A global perspective. World Economy, 28(6), 841-871. doi.org/10.1111/j.14679701.2005.00709.x

Wilson, J. S., Mann, C. L., \& Otsuki, T. (2005b). Assessing the potential benefit of trade facilitation: A global perspective. In P. Dee \& M. Ferrantino (Eds.). Quantitative methods for assessing the effects of non-tariff measures and trade facilitation (pp. 121-160). World Scientific Publishing Co. Pte. Ltd.

World Bank. (2009). Doing Business 2010: Reforming through Difficult Times. Washington, DC: The World Bank. 
Received on $6^{\text {th }}$ May 2021, after revision, accepted for publication on $25^{\text {th }}$ November 2021

Published online on $6^{\text {th }}$ December 2021

Anh Thu Nguyen, gained her Ph.D. in Economics at Yokohama National University, Japan, in 2009. She specialized in International Development. Presently, she is the Vice Rector of the University of Economics and Business of Vietnam National University, Hanoi, and the Director of the Vietnam Institute for Economic and Policy Research (VEPR). The key research areas she is dedicated to are international economic integration and green growth.

Thi Mai Thanh Tran is a researcher at the Vietnam Institute of Economics of the Vietnam Academy of Social Sciences. Her research is focused on the international economic integration of Vietnam and ASEAN. 


\title{
UTICAJI PERFORMANSI TRGOVINSKIH OLAKŠICA NA TRGOVINSKE TOKOVE U ASOCIJACIJI NACIJA JUGOISTOČNE AZIJE
}

\author{
Anh Thu Nguyen ${ }^{1} \mathrm{i}$ Thi Mai Thanh Tran² \\ ${ }^{1}$ Vietnam National University, University of Business and Economics, Hanoi, Vietnam \\ ${ }^{2}$ Vietnam Accademy of Social Sciences, Vietnam Institute of Economics, Hanoi, Vietnam
}

\begin{abstract}
Asocijacija nacija jugoistočne Azije (ASEAN) smatra da su trgovinske olakšice pokretačka sila koja vodi ka formiranju jednog tržišta i jedne proizvodne baze. U ovom radu se konstruiše pokazatelj uspešnosti Asocijacije nacija jugoistočne Azije za merenje performansi strateških planova trgovinskih olakšica koje sprovode države članice Asocijacije. U radu se dalje koristi strukturni gravitacioni model u cilju procene uticaja performansi trgovinskih olakšica na trgovinske tokove u Asocijaciji. Konstatuje se da se pokazatelj ublažavanja netarifnih prepreka (NTM) i institucionalne koordinacije, s jedne strane, i pokazatelj uključenosti država članica Asocijacije, s druge, najuspešnije ostvaruju u Asocijaciji u periodu 2017-2019. Ta dva pokazatelja, takođe, imaju najjači uticaj na trgovinske tokove u Asocijaciji, posebno kada se radi o vanregionalnoj trgovini država članica Asocijacije.
\end{abstract}

Ključne reči: ASEAN, trgovinske olakšice, trgovinski tokovi

JEL Classification: F100, F140, F150 